\title{
The Roles of Leadership, Vision, and Empowerment in Born Global Companies
}

\author{
Soma Chhotray $^{1} \cdot$ Olof Sivertsson $^{1} \cdot$ Joakim Tell $^{1}$ \\ Published online: 25 May 2017 \\ (C) The Author(s) 2017. This article is an open access publication
}

\begin{abstract}
This article explores the roles of leadership, vision, and empowerment in two Swedish born global companies. Using case studies and interviews with employees and managers, the article examines how managers can lead their companies by creating a vision and empowering their employees. The findings indicate that a company vision should reflect a culture that supports the employees' daily activities and decisions. A leadership style that features delegation of responsibility and recognition of employee work autonomy empowers employees in a way that can advance the development and internationalization of the born global company, especially in situations when top managers are often away from company headquarters.
\end{abstract}

Resumen El presente artículo explora la influencia que ejercen el liderazgo y la visión compartida sobre el empoderamiento en empleados de empresas nacidas globales. Estudios de caso, basados en entrevistas con empleados y gerentes, examinaron la manera como los directivos pueden dirigir y desarrollar sus empresas, a través de la definición de una visión compartida y el empoderamiento de sus empleados. Este estudio indica que una visión compartida de la empresa debe verse reflejada en una cultura que apoya las actividades cotidianas y las decisiones de los empleados. En una empresa nacida global, donde el gerente se encuentra ausente gran parte del tiempo, el estilo de liderazgo debe estar orientado a la delegación de responsabilidades y la autonomía en el trabajo de los empleados, que los empodere para contribuir al desarrollo e internacionalización de la empresa.

Joakim Tell

Joakim.tell@hh.se

Soma Chhotray

soma0412@gmail.com

Olof Sivertsson

sivertsson.olof@gmail.com

1 Halmstad University, Halmstad, Sweden 
Keywords Born globals · Vision · Leadership · Empowerment

Palabras clave empresas nacidas globales $\cdot$ visión compartida $\cdot$ liderazgo y empoderamiento

\section{Summary Highlights}

Contributions The article's main contribution is its exploration of the supportive and egalitarian leadership style that empowers employees as they make decisions and take actions. As a result of this responsibility and autonomy, the employees of this research were more committed to their companies and to their work.

Research Questions/Purpose The purpose of this article is to examine how managers use leadership skills and the company vision to empower employees at born global companies.

Basic Methods and Information Empirical data come from case studies based on interviews with employees and managers at two born global companies in Sweden.

Results/Findings Previous studies have shown that a shared organizational vision is important in guiding and controlling organizations. Much of the literature suggests that vision is very crucial to organizational success. However, in this article, we suggest that while vision has an important role in company activities, employees may not directly refer to, or rely on, such visions as they make their everyday decisions and take everyday actions. An effective vision, which must be formulated and promoted among an organization's members, provides a clear strategy that guides the daily work.

Theoretical Implications and Recommendations The article's findings reveal that a company's vision should reflect a culture that supports the employees' daily activities and decisions. A leadership style that features delegation of responsibility and recognition of employee work autonomy empowers employees in a way that can advance the development and internationalization of the born global company, especially in situations when top managers are often away.

Practical Implications and Recommendations The article highlights the importance of a supportive organizational culture in which employees have delegated autonomy and decision-making authority. The employees in this study took pride in this responsibility because they typically did not have to wait for specific orders or depend on others' decisions. When employees encountered problems that required assistance, they collected information from the relevant sources. In this way, they contributed to the development of the company.

Future Research Suggestions Although the literature deals extensively with the importance of vision, the focus is often on an organizational vision that is the result of a top-down construction rather than a bottom-up construction. We suggest that more 
empirical research is needed on the importance of vision from the employee perspective and at various organizational layers.

\section{Introduction}

In recent decades, some managerial researchers have focused on international new ventures, or as they are often called, "born globals" (BGs) ${ }^{1}$ (e.g., Madsen and Servais 1997; Oviatt and McDougall 1997; Cavusgil and Knight 2009; Knight 2015). Several studies from the mid-1990s reveal that more and more small- and medium-sized enterprises (SMEs), from their founding, seek an international presence (Oviatt et al. 1994; Oviatt and McDougall 1995). Knight and Cavusgil (2004) attribute the dramatic increase in global business activity and the flourishing of BGs to the emergence of advanced technologies and to the increase in global infrastructures.

What do we know about the phenomenon of the early internationalization of BGs? Rialp et al. (2005) reviewed the academic literature (38 theoretical and empirical studies) in the international entrepreneurship field between 1993 and 2003. Their aim was to identify the main empirical findings in the literature and to recommend further theoretical development that could explain the internationalization of firms. This development is still considered an emerging phenomenon. They created a taxonomy for sorting the 38 studies using research focus (explanatory - a theory building or hypothesis testing approach or exploratory - a comparative or descriptive approach) and using type of research (theoretical or empirical). They concluded the following (p. 154):

So far in this field, both quantitative- and qualitative-oriented lines of research coexist, although empirical studies of a rather descriptive, comparative, and/or exploratory nature seemingly predominate over highly consistent theoretical studies and rigorous, well-supported proposition- and/or hypothesis-testing empirical research.

Servantie et al. (2016) conducted a bibliometric analysis of 567 articles on international entrepreneurship that were published between 1989 and 2015. They identified five clusters that support the findings in the articles that Rialp et al. (2005) reviewed. These five clusters are the following:

- Internationalization of SMEs

- International new ventures

- BG firms and networks

- Resource-based view of the firm

- Conceptualization and synthesis

Studies of BGs typically describe the phenomenon of internationalization (Crick 2009), comparisons with domestic ventures (Oviatt et al. 2003), marketing (Mort et al.

\footnotetext{
${ }^{1}$ Knight and Cavusgil (2004) define BGs as business organizations that, from or near their founding, seek superior international business performance from the application of knowledge-based resources in the sale of outputs in multiple countries.
} 
2012), and branding strategies (Gabrielsson 2005). Other areas of research interest are entrepreneurial characteristics of BG managers such as international experience, background, or childhood (Ghannad 2013); innovation (Kunday and Șengüler 2015); and international entrepreneurship in universities (Etemad 2016).

Some authors, however, are rather critical of the development of the research field dealing with BGs. Cesinger et al. (2012, p. 173) criticize the past 20 years of research on business internationalization as follows:

The phenomenon of rapid internationalizing ventures has neither reached a common understanding nor has contributed to any further insights into theory building.

Aspelund et al. (2007), in their review of the field, point to the lack of coherent definitions and the need for more theory-driven research. Although some research deals with the entrepreneur and his/her mindset (Nummela et al. 2004), there is a scarcity of research on the management of BGs (Andersson and Florén 2011).

Is there a difference in the management of a BG compared to the management of an "ordinary company"? There is, of course, much similarity in the managerial work of all firms (Mintzberg 1973). Yet it seems that the BG manager has a particularly strong entrepreneurial mindset (Taney 2012). As a result, the BG manager, who is especially prone to take risks and to aggressively compete in international markets (Cesinger et al. 2012), is likely more dependent than other managers on his/her colleagues, for example, on management teams (Andersson and Evangelista 2006).

Cesinger et al. (2012, p. 174) describe the earlier challenge for BG managers as the "managerial art of overcoming information gaps and building experiential knowledge about foreign markets". More recently, say in the last 10 years, the focus has shifted. Today, the challenge is how to effectively coordinate scarce resources (human and financial) and customer demands. This means that BG managers have to communicate their intentions or mindset to others (ultimately, to all stakeholders including the employees). In addressing this challenge, the management literature recommends that leaders adopt a transformational leadership style, guided by a vision based on a supportive culture.

However, there seems to be a gap in the research on the relationship between leadership, vision, and empowerment in the study of BGs. For example, Wictor and Andersson (2012) and Wictor (2016) emphasize the need for more studies on vision (as well as on leadership and communication) in BGs that take the employees' perspective. Foster and Akdere (2007) found only a few empirical studies on employees' relationship to organizational vision. Empowerment, which is essential to the success of an organization, may in large part depend on the trust between managers and employees as they support a common vision (Pech 2009; Block 2016). In their study of BGs, Efrat and Shoham (2012) find that while short-term performance is mostly driven by external factors (e.g., company environment), long-term performance is mostly driven by internal factors (e.g., company culture). The latter factors are more critical for companies' survival and success.

In general, the management literature concludes that the successful organization requires a clear vision and good leadership. Another requirement is a group of committed employees who support the organization's vision. An interesting question is the following: Are these requirements even more crucial for the success of BGs? 
In their study of managerial behavior, Andersson and Florén (2011) point to situations in which managers in small, international firms are more proactive, delegate more operational activities, and devote more time to planned strategic activities connected with the international expansion than managers in small, non-international firms. Pitts (2005) examines the relationship between empowerment and performance in a study that explores whether organizations with empowering managers are more or less effective than organizations with managers who do not empower their employees. The concept of empowerment can be viewed as a motivational vehicle that encourages employees to want to influence their work roles and work context (Butts et al. 2009; Spreitzer 1995). However, empowerment also places pressure on the employees. Quinn and Spreitzer (1997, p. 37) write that empowered "employees must learn to take initiative, be creative, and accept responsibility for their actions."

In short, it appears that much more research in the field of BGs is needed if we are to advance the scholarship on the internationalization of newly founded firms. According to Cavusgil and Knight (2015, p. 13), the following lines of inquiry on BGs may be especially useful:

- Better articulated and integrated theoretical frameworks will assist in formulating new explanations, research propositions, and hypotheses.

- More use of quantitative and qualitative approaches will produce a larger empirical database. Longitudinal surveys that employ large-scale samples of representative firms, combined with comparative case studies of BG companies and non-BG companies, are particularly needed.

A principal inspiration for the research reported on in this article is transformational leadership theory. Smith et al. (2004, p. 84) describe transformational leadership as the kind of leadership "when a leader inspires followers to share a vision, empowering them to achieve the vision, and provides the resources necessary for developing their personal potential." Transformational leaders can be role models who focus on their followers' need for growth (Bass and Avolio 1994).

Organization researchers have often addressed the idea that management can implement strategies by promoting and encouraging a vision and the idea that a company's culture is built through active participation by all actors. The BG research has also addressed these ideas, particularly in the last 15 years (see, for instance, Spence 2003). The literature, however, is unclear on how to use a company vision to delegate decision-making and responsibility to employees. This is especially important when, as is often the case with BGs, top managers are away from the center of decision-making travelling on business.

This article examines how BG managers use leadership skills and a company vision to empower their employees. Case studies are used to examine the interaction between managers and at two BGs.

\section{The Theoretical Framework}

The theoretical framework for this research is built on three constructs: vision, leadership, and empowerment. We use transformational leadership theory as we focus on the relationships among vision, leadership, and empowerment. This focus is consistent 
with Aspelund et al.'s (2007) finding that path dependence seems to have a long-term effect on international development and performance. Thus, our investigation responds to the call for a deeper understanding of how leadership and company vision at BGs relate to employee empowerment.

\section{Vision}

A company (or organizational) vision is the company's guiding star that points to opportunities and at the same time controls the course ahead. According to Zaccaro and Banks (2004), a company must have strategic flexibility that allows it to achieve competitive advantage. To ensure that employees support a company's vision, managers and other leaders must act strategically as they explain and disseminate that vision. As Andersson and Evangelista (2006) state, entrepreneurs of BGs, who make the important strategic decisions, must convince employees to share the company vision. A BG cannot succeed if its entrepreneur is unsuccessful in promoting this vision.

Leaders of BGs use the company vision to control the company and to "think new" by creating a culture suitable for a global organization (Wictor and Andersson 2012). However, if a leader's vision is too narrow and too exclusionary, the vision may not have its intended effect. If employees are to commit to a company vision, then that vision must be sufficiently general and inclusive that it becomes a shared vision (Lipton 1996). To gain that commitment, the developers of a company vision must consider employees' personal goals and values. It is essential that employees support a company vision because they want to, not because they have to.

Several studies discuss how important it is for employees to understand and share the company vision. This is a prerequisite for effective empowerment programs (Quinn and Spreitzer 1997; Randolph 1995). Kantabutra and Avery (2010) find that managers must convince employees to invest in the shared vision if they are to follow its directions and achieve its desired results. Thus, to communicate the organizational vision, entrepreneurs/leaders/managers must connect that vision to specific and practical actions. In this way, employees comprehend how the vision is actualized. Kantabutra and Avery (2010, p. 38) describe an ideal vision as neither too abstract nor too specific and yet inspiring:

An inspiring vision that is clear, brief, abstract, challenging, and stable will not be able to attract effective commitment from followers unless it offers a compelling view of a better future. Without a desirable future picture, followers are unlikely to be drawn from where they presently are to work toward the vision.

\section{Leadership}

We find numerous definitions and discussions of leadership in its various forms in the literature. Bass (1996) states that transformational leadership has four dimensions: charisma or idealized influence, inspirational motivation, intellectual stimulation, and individualized consideration. Bass (1999) expands this description in a later article by stating that idealized influence and inspirational leadership are displayed when the 
leader envisions a desirable future, articulates how it can be achieved, sets an example to be followed, sets high standards of performance, and shows determination and confidence such that followers identify with such leadership.

However, Conger and Kanungo (1998) conclude that the "charisma" dimension is the most influential dimension of transformational leadership. Nevertheless, it may be argued that the ideas on transformational leadership and charismatic leadership overlap. In their study, Judge and Picollo (2004) confirm their hypothesis that transformational leadership and charismatic leadership share similar traits. Conger and Kanungo (1998) admit there is a little real difference between these two terms.

In a study of teams under transformational leadership, Bass (1999) confirms the moderate and positive effect of such leadership on empowerment. He also finds that teams under transformational leaders are more effective. Hence, leadership that fosters an open, innovative, and healthy climate plus team spirit should promote the use of motivating role models, clear communications, and a shared vision with a common goal.

As previous research generally concludes, people in leadership positions should take responsibility for building a culture that persuades employees to support the organization's vision and, at the same time, that creates an open atmosphere with free communication, respect for new ideas, acceptance of failures, and a collective spirit of working toward a common goal. Employee empowerment, described next, may be an essential element of this culture.

\section{Empowerment}

Various synonyms are used for empowerment. A commonly used synonym is motivation. Yet there is a slight difference between empowerment and motivation. Motivation is more often used in analyses at the level of the individual whereas empowerment expands on this narrow, individualistic perspective. Empowerment refers to the selflevel as well as the interpersonal level (Lee and Koh 2001).

Randolph (1995) concludes that empowerment means teaming with others through sharing information and creating new structures that use and develop people's talents. Other research identifies seven important dimensions of empowerment: power, decision-making, information, autonomy, initiative and creativity, knowledge and skills, and responsibility. This itemization of the empowerment dimensions is limited to managers' authority or to employees' abilities (Petter et al. 2002). Seibert et al. (2004) agree that managers who seek to empower employees should understand that employees perceive the empowerment climate as one of information sharing, clear boundaries, and team accountability.

Therefore, managers who share information should also set certain boundaries as they promote a spirit of team effort and responsibility. According to Pitts (2005), managers are more likely to empower subordinates in environments with greater task difficulty and fewer resources than in environments with simpler tasks and more resources. It is important to understand how managers cope with challenging situations as they empower their employees to complete difficult tasks.

The research suggests that employee empowerment is a multidimensional concept that describes how leaders lead, how individuals react, how peers interact, and how work-related processes are structured (Honold 1997). Özaralli (2003) states that a 
fundamental characteristic of transformational leadership is the ability to create an organizational environment in which followers feel empowered to seek innovative work approaches without fear of penalty.

Dewettinck and Ameijde (2010) list the following key managerial steps in employee empowerment: involving employees in decision-making, showing employees that their work contributes positively to organizational processes, informing employees of organizational changes, connecting employees to the workplace through job satisfaction, and showing support for employees as they face organizational changes.

In their research on empowerment, Greasley et al. (2008) reach an interesting conclusion. They find that most employees do not recognize the term empowerment. Instead, employees are more familiar with terms such as decision-making, problem solving, acceptance of responsibility, control, and work commitment. In their conceptual framework, based on a study of Polish SMEs, Michna et al. (2011) conclude that empowerment, innovativeness, and internationalization intertwine and interconnect in a network of feedback relationships.

Some researchers present empowerment as part of charismatic leadership (Choi 2006). Although, as described earlier, various researchers present their own ideas around empowerment, our concern is with the concept of empowerment that is consistent with vision and charismatic leadership. Hence, the factors related to this understanding of empowerment are the following:

- Decision-making (Greasley et al. 2008; Petter et al. 2002)

- Information sharing (Randolph 1995; Quinn and Spreitzer 1997)

- Responsibility: acceptance of responsibility (Greasley et al. 2008; Yang and Choi 2009) and skills and responsibility (Petter et al. 2002)

- Passion or self-motivation for work: autonomy, initiative (Butts et al. 2009; Spreitzer, 1995) and control, and willingness to work (Greasley et al. 2008).

\section{Our Conceptual Framework}

Based on this literature, we find a strong interconnection among vision, leadership, employee empowerment, and a growing BG. Figure 1 presents our conceptual framework with variables derived from theory. We use this framework in our analysis of the two BG cases described in this article. We recognize the challenge inherent in measuring performance drivers. Carton and Hofer (2006), in describing this challenge, claim there are almost as many measures as studies. Nevertheless, it is important to be transparent and to motivate the measures. In our study, we operationalize the three constructs of vision, leadership, and empowerment in our conceptual framework.

\section{The BG Manager}

Knight and Cavusgil (2004) state that BGs acquire a substantial, fundamental base of international experience and knowledge early in their life cycle. Traditional multinational enterprises (MNEs) typically take far longer to acquire such experience and 


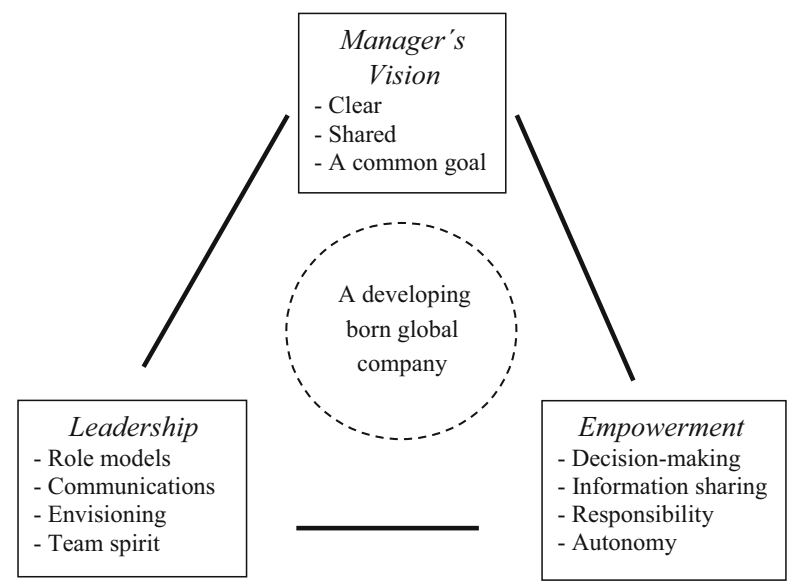

Fig. 1 Conceptual framework for the analysis of the relationships among vision, leadership, and empowerment in BG companies

knowledge. Because BG managers spend a lot of time travelling to other countries where they meet other cultures, they have to develop a leadership style that is respectful and understanding of other people (Harveston et al. 2000). It is essential that their leadership style is especially tactful toward and sensitive to other cultures. Moreover, it is a leadership style adaptable to the company culture in which employees are treated with tact and sensitivity.

The manager is the key player responsible for guiding an organization in the right direction. We identify the manager as a key player in BGs. In describing the ideal vision for a BG from the BG manager's perspective, Andersson and Wictor (2003) claim that the vision should be clear, inclusive, and shared with the employees. With such a vision, everyone works toward a common goal (Quinn and Spreitzer 1997). BG managers with an organizational vision can create a more participative climate and more empowering conditions that allow organizational members to assume the authority to take actions that support and promote the vision (Özaralli 2003).

\section{Research Method}

In their conceptual framework, Knight and Cavusgil (2004) define superior performance in international markets as the extent to which financial and other goals are achieved as a function of business strategies. We describe the two BGs in our case studies as "growing" because they are market leaders in the Scandinavian domestic market and have significantly increased in size in recent years. The goal of both BGs is to become a world market leader in the sale of their products. One commonality between the two BGs is that each has had the same manager for more than a decade. At both companies, employee turnover is low, and the number of employees has increased over the years.

The empirical data for our study come primarily from interviews with the managers and the employees at the two BGs (Appendixes 1 and 2 list the interview questions). 
The theories used in the analysis of the empirical data are structured around the three constructs of our conceptual framework: vision, leadership, and empowerment.

We selected the two companies from a group of BGs that had previously participated in a research project at our university. The respondents were two managers (the BG entrepreneurs) and six employees. We conducted eight interviews (a manager and three employees at each company). We are aware that eight interviews are too few to statistically assert a connection among vision, leadership, and empowerment in terms of company success. However, our aims were to address a complex topic in an interesting way (Eisenhardt et al. 2016) and to gain insightful observations on the organizational dynamics of BGs. We assume that the organizational world is socially constructed (Gioia et al. 2013). We also relate the interview responses to other studies in the research field on BGs in order to add depth to our analysis and conclusions.

The two BGs of our study, which are each almost 20 years old, are market leaders in their domestic and international markets. The managers, who are global leaders and travel frequently, have the challenge of empowering their employees. The companies' vision statements and leadership styles have changed relatively little since early 2000. Table 1 presents the two companies that we identify as company A and company $\mathrm{B}$.

We conducted face-to-face interviews with the manager and three employees at company A and with the manager and three employees at company B. We selected interview respondents on the basis of their position and experience at their companies and their availability. We described the purpose of the interview and its main theme to each respondent. The interviews were conducted at the companies. Each set of interviews was conducted in 1 day. Each interview lasted approximately $1 \mathrm{~h}$.

Prior to these interviews, we collected secondary data from the companies' records and websites and from industry journals. These secondary data gave us background information on the companies' history, vision, leadership, markets, and products. During the interviews, we acquired additional data on the companies. To supplement the questions in our interview guides (see Appendixes 1 and 2), we invited the respondents to make spontaneous comments.

We analyzed our empirical data in several steps. First, we transcribed the recorded interviews and organized our notes. Next, we shared our interpretation of the interviews with the respondents. Then, we analyzed the interviews using our conceptual framework.

Table 1 The born global companies in the study

\begin{tabular}{lllll}
\hline Name & Vision & Industry & No. of employees in Sweden & Sales \\
\hline Company A & $\begin{array}{l}\text { To become the world's number } \\
1 \text { company by brand. }\end{array}$ & Industrial products & 30 & 12 MUSD \\
Company B & $\begin{array}{l}\text { To be the number 1 global } \\
\text { supplier of high-quality } \\
\text { products to the medical } \\
\text { industry. }\end{array}$ & Medical products & 131 & 27 MUSD \\
\hline
\end{tabular}




\section{The Exploratory Case Studies}

\section{Company A}

Company A is a medium-sized manufacturing and distributing company with 30 employees. The company sells high-quality machines and other equipment to manufacturers. It is a market leader in Sweden and one of the top three leaders in the global market place. Some of its customers are well-known multinational corporations that have been associated with company A for a decade. The list of customers increases annually. Company A's headquarters are in central Sweden. It has a daughter (i.e., subsidiary) company in the USA and another in China. In addition, company A operates in 50 countries in a strong distribution channel, and has acquired another company in the same industry. Company A has increased its sales in 10 of the last 13 years. Its aim is to continue this record of growth. Management has remained constant in the last 13 years.

Company A has long-term relationships with numerous global customers. These customers are in various industries, such as automobiles, heavy metal manufacturing, hydraulics, engineering tools, food processing, and many more.

Company A operates as a completely flat organization with a typical Scandinavia management style. It has three organizational layers: a manager, a five-member management team (including the manager), and employees from various departments. There is really no middle layer between the management team and the employees. Their relationship is described as more egalitarian than authoritarian. Doors to offices are open, and pets are allowed in offices. We observed staff at all levels informally talking to colleagues in their offices about various issues. The employees are encouraged to suggest improvements that could benefit the company.

Company A's vision is to become the world's number 1 company by brand. Its clearly stated vision statement is communicated via printed media and is also posted on various company walls, including a wall in the coffee room. Our interviews revealed that the employees relate differently to the vision statement. One employee said that the vision was hard to relate to, but the mission was more relevant. Nevertheless, the employees agreed that the company vision was repeatedly communicated to them in budget discussions, in other meetings, and in reevaluations of targets.

The respondents described company A's work culture as very open and informal with a good deal of work autonomy. Initially, at the company's founding, the manager exercised tighter control; today, the management team exercises a looser form of control. The current management team believes strongly in sharing information with the employees in a transparent manner. In its growth phase, company A's management realized that the company needed a good leadership team capable of formulating and pursuing a strategic company vision. Hence, in 2000, there was a leadership change that resulted in the creation of a structured management team. Such a change is not uncommon when it is realized that a BG, which was initially managed by a single individual, requires a different management structure as its international presence increases.

Company A's management team has an even larger role when the manager travels abroad. He is absent from the Swedish headquarters nearly 90 to 100 workdays annually. Because the management team's responsibilities and roles are clearly defined, 
the employees know whom to approach about which areas or problems. Thus, business is "as usual" in the absence of the manager.

The manager at company A described the two reasons for his work motivation: a competitive salary and work that encourages personal development. The employees said that they were motivated by their bonus, the commission structure, and their work autonomy. Training and education is a constant and regular process in company A. In addition, innovation training, leading to career advancement, is available for all employees.

\section{Company B}

Company B is a medium-sized manufacturing and distributing company with some 130 employees in Sweden. The company, which sells a wide range of high-quality products to the medical industry, is a market leader in northern Europe. Company B's ambition is to be the number 1 global supplier of such products. Its headquarters are in southern Sweden. The company has a daughter (i.e., subsidiary) company in the USA. The company has strong distribution channels in some 50 countries globally. The company has increased its sales three times in the last 10 years and aims to continue this growth. High-quality, innovative products and good service are the most important factors in the company strategy.

Company B's vision statement appears on the company's website and intranet, is posted near the entrance to company headquarters, and is a feature of sales meetings. It is evident that the company wants high visibility for its vision statement. According to the manager, employees understand the vision while still recognizing improvements to it are possible. The manager is convinced that the vision should be realistic and achievable. One employee said that the vision is more a general feeling rather than a topic of discussion. Another employee said that while employees are aware of the vision, they also think that company B's slogan is more important.

Company B's manager, who believes in decentralization, thinks that the best decisions are made as close to the problem as possible. Although he recognizes that employees will sometimes make mistakes, he does not think that his role is to oversee all their decisions. He thinks that his role is to be supportive of the employees and their decisions. The employees agree on this understanding of the manager's role. They said that he is very supportive of their decisions and grants them the autonomy to make their own decisions. The manager tries to be as open as possible, both on a professional level and on a personal level. In sum, the employees regard the manager as another team member. They understand, however, that some information is privileged. Therefore, they do not expect the manager to share such information.

Company B's employees are motivated in their work mostly because of the decision-making latitude allowed them. As a result, they take individual responsibility and try to deliver the best possible performance. The high-quality products are also an important motivating factor for the employees. They take pride in these products. As company B continually searches for new and better products and solutions, the employees are motivated to be always one step ahead of the market. 


\section{Analysis}

Using the data from the interviews, we coded the main constructs (vision, leadership, and empowerment) of our conceptual framework and traced their relationships to the development of the two BGs. Table 2 presents the summary of that analysis.

Both company A and company B encourage an open culture in which everyone employed is very approachable and cooperates in teamwork to meet the customers' demands. An employee described the company manager: I regard him as friend and colleague. We are like a football team.

Both company A and company B give their employees considerable decisionmaking freedom. This creates company cultures that the managers and the employees appreciate. Thus, the employees are empowered in their work and can make the best

Table 2 Examples of vision, leadership, and empowerment at the BGS in the study

\begin{tabular}{|c|c|c|c|}
\hline & Vision & Leadership & Empowerment \\
\hline $\begin{array}{l}\text { Company } \\
\text { A }\end{array}$ & $\begin{array}{l}\text { The vision of the company, } \\
\text { which is clear and shared in } \\
\text { the organization in different } \\
\text { forms, seems to be } \\
\text { embedded in the process of } \\
\text { daily work. An employee } \\
\text { said: The vision-it is } \\
\text { included in the quality } \\
\text { system, so we act } \\
\text { accordingly. We saw that } \\
\text { the vision is evident in } \\
\text { different forms and is shared } \\
\text { by everyone. However, the } \\
\text { various employees perceive } \\
\text { the vision slightly } \\
\text { differently. }\end{array}$ & $\begin{array}{l}\text { This company has a flat } \\
\text { organization structure and } \\
\text { encourages teamwork to } \\
\text { meet the demands of the } \\
\text { customers. When the } \\
\text { employees were asked to } \\
\text { comment on the manager's } \\
\text { leadership style, they } \\
\text { described it as an informal, } \\
\text { inclusive way of working. }\end{array}$ & $\begin{array}{l}\text { The manager of the company } \\
\text { is a strong believer in shared } \\
\text { responsibility. He } \\
\text { encourages the employees } \\
\text { to take decisions on their } \\
\text { own. The company also } \\
\text { expects the employees to try } \\
\text { to solve problems. The } \\
\text { manager said that he tells } \\
\text { the employees: I don't want } \\
\text { you to wait for an answer if } \\
\text { there is a problem. I expect } \\
\text { you to solve it, and if it is } \\
\text { not the right decision, at } \\
\text { least you made a decision. If } \\
\text { there is anything wrong, we } \\
\text { will discuss the problem and } \\
\text { solve it. We will make sure } \\
\text { that the mistake does not } \\
\text { happen again. }\end{array}$ \\
\hline $\begin{array}{l}\text { Company } \\
\text { B }\end{array}$ & $\begin{array}{l}\text { The important aspect of the } \\
\text { vision is that people are the } \\
\text { best at what they do and } \\
\text { where they want to be. This } \\
\text { indicates that the vision has } \\
\text { been integrated into daily } \\
\text { working routines. An } \\
\text { employee said: I don't think } \\
\text { about the vision every day, } \\
\text { but it's inspiring that we } \\
\text { have very good products } \\
\text { that are asked for from all } \\
\text { over the world. }\end{array}$ & $\begin{array}{l}\text { The leadership style of the } \\
\text { manager is described as } \\
\text { very close to the textbook } \\
\text { example of transformational } \\
\text { leadership. The } \\
\text { decision-making power } \\
\text { seems to be essential for the } \\
\text { motivation of employees. } \\
\text { An employee described } \\
\text { working with the manager: I } \\
\text { like working with him be- } \\
\text { cause he is very encourag- } \\
\text { ing and allows me to take } \\
\text { my own decisions. I don't } \\
\text { have to check everything } \\
\text { with him. }\end{array}$ & $\begin{array}{l}\text { The delegated decision-making } \\
\text { authority for employees } \\
\text { seems to be one of the most } \\
\text { appreciated work condi- } \\
\text { tions. In addition, the em- } \\
\text { ployees appreciate the } \\
\text { chance to learn together } \\
\text { from their mistakes. An } \\
\text { employee stated: I don't } \\
\text { have to ask for everything. } \\
\text { It's a very open climate, and } \\
\text { the manager expects me to } \\
\text { take my own decisions. I } \\
\text { think that this is the most } \\
\text { important thing for me. }\end{array}$ \\
\hline
\end{tabular}


use of their skills. Decision-making authority seems to be a key motivating factor for the employees. When mistakes are made, they are corrected in a spirit of mutual cooperation. With this employee empowerment, a positive work atmosphere is created that contributes to the BGs' success.

\section{Discussion and Conclusion}

A BG is a special company that, from its founding, is committed to operating in the global market. Typically, a BG's vision reflects the ambition to become a world leader in its field, if not the world leader. We found that the respondents at company A and company B shared in and supported that vision. However, we also found that the managers supported that vision more than the employees. For example, some employees found the vision somewhat difficult to relate to. We conclude the two companies' visions motivated the managers more than the employees. Nevertheless, the employees' responses indicated that their work attitude and performance were consistent with the visions. They generally think that the companies' products support the visions.

The interview responses revealed that company vision at both company $\mathrm{A}$ and company B points to opportunities and at the same time controls the course ahead. This is true for both the strategic work and the operational work. However, it took some careful analysis of the interview data before we reached this conclusion. The explanation is that vision as a managerial mindset (Harveston et al. 2000; Nummela et al. 2004) is not immediately evident. Therefore, we emphasize the importance of our dialogue with the respondents and the necessity of reflection on their responses by the research group. Making sense of qualitative empirical data, such as our interviews produced, requires a period of time for discussion and analysis, in particular as far as the leadership role of the managers and the empowerment of the employees.

\section{Implications for Managers}

The managers at the two BGs created a supportive culture. A key element of this culture is the delegation of decision-making to employees. Both the employees and their companies benefit from this work autonomy. Typically, the employees do not need to wait for specific orders or to depend on others' decisions. They work actively and independently to find solutions to problems.

Moreover, this culture means that the employees are willing to help both the company and their coemployees succeed. It is a source of pride for them to be a part of something larger than themselves and to see that their contribution benefits their company. A culture such as this is essential for a BG because, given its global nature, a manager must often travel abroad if the company is to grow (Andersson and Florén 2011). This culture also emphasizes the importance of the company brand that the employees championed and promoted.

The employees had no hesitation when responding to the following questions: What do you do? How do you do it? Why are you good at it? What does your future hold? Yet their responses to these questions did not directly reflect the companies' vision 
statements. The employees' outlook is specific and realistic rather than visionary. They know the strengths of their products, and they knew why the customers buy their products. For the employees, product knowledge influences their daily work rather than the company vision.

In addition, the employees described the atmosphere and the culture in the organization as almost family-friendly. Like the harmony and common purpose found in wellfunctioning families, the employees, as well as the managers, were like-minded in their pursuit to be the best in all their activities. In fact, they have an attitude of almost "us against the world."

\section{Implications for Theory}

Few studies explicitly address leadership/management at BGs. This study contributes to leadership theory with its finding that managers (i.e., all leaders) require the support of their followers. This means that leadership and empowerment are closely related.

The supportive and egalitarian leadership style of the managers at the two BGs was the most important factor that enabled employee empowerment. This leadership style promoted independence among employees. As a result of this responsibility, the employees were very committed to their companies and to their work. They appreciated the trust that the managers had in them.

Previous studies have shown that a shared organizational vision is important in guiding and controlling organizations (e.g., Kantabutra and Avery 2010). Much of the literature suggests that vision is very crucial to organizational success. However, we suggest that while vision has its role in company affairs, employees may not directly refer to, or rely on, such visions as they make their everyday decisions and take their everyday actions. We agree with Zaccaro and Banks (2004) that instead of using a vision to guide and motivate employees, it is more important to have a clear strategy and slogans that guide the daily work.

\section{Suggestions for Future Research}

Our study deals with how managers use leadership skills and the company vision to empower employees at two medium-sized BGs. A parallel investigation might deal with the same topic from the perspective of larger BGs or the perspective of multinational firms that were not global players at their founding. It may be of interest to study vision and empowerment separately for such companies.

We also think that more research is needed on the empowerment of employees at BGs. A larger dataset and/or a quantitative study may reveal factors other than decision-making and work autonomy as forms of empowerment. In connection with this suggestion, it would also be interesting to contrast our study of BGs that have extended employment/management tenure with BGs that do not have such tenure. Furthermore, it would be interesting to examine why managers and employees emphasize financial benefits as empowering factors.

Finally, although the literature deals extensively with the importance of vision, the focus is on an organizational vision that is the result of a top-down construction rather 
than a bottom-up construction. We suggest that more empirical research is needed on understanding the importance of vision from the employee perspective and at various layers of the organization.

\section{Appendix 1 Interview guide for managers}

Please tell us briefly about the journey of the company and its position today.

\section{Vision}

1. Can you describe the vision of the company and how it is communicated in the organization?

2. Do you think that the staff connects with the vision and are well aware it?

3. Do you believe in communicating or sharing the organizational information such as vision, action plans. etc. with the employees? Or is there anything else that is more important?

4. Do you have a special strategic structure in your mind or a design that fulfills the vision of the company? Can you share with us your thoughts on this?

\section{Leadership}

5. Describe yourself as leader.

6. Has your leadership been important to the company, and has it changed over the years?

7. How would you describe the internal culture or working atmosphere of the company?

- Freedom of expression

- Openness

- Team spirit or collective effort, etc.

8. How well do you connect with the employees and in what forms?

9. How independent are people at different levels in handling their work?

10. Do you want your employees to be like you and act like you, but still retain their skills and competences?

11. Are you aware of problems that occur in the company? Do the employees solve problems without your involvement?

12. Do you try to inspire and motivate your employees through acting as a role model where you take decisions according to the organization's vision and goals?

\section{Empowerment}

13. How do you empower the employees?

14. What other forms of motivation are used? 
15. How well, and to what extent, do you share information with the employees with respect to the achievements, hurdles, new plans, changes in plans, or any other crucial info? Do you think it is important? If yes, why? If not, why?

16. Do you feel that the employees can achieve their individual goals while working for the success of the company? And how are you working with these kinds of questions?

17. Approximately how many hours do you work per week? How many of your work hours are spent in the office when you are available for employees?

18. As travelling is important part of your schedule, and you travel often, how would you describe the impact of your presence or absence at the company?

19. Do you allow your employees to take risks? Or do you expect them to always take decisions where the anticipated outcome is positive? How much risk do you allow? What are the consequences of failure?

20. Is it beneficial for employees to take their own decision as long as those decisions are consistent with the company's vision?

21. Do the employees take decisions and share information that normally is not their responsibility without talking to you or another manager?

\section{Closing question}

22. Imaginary scenario: Let us say that you are away from the company a week or so. This absence is unplanned. What do you would think would happen in the company?

\section{Appendix 2 Interview guide for employees}

Please tell us briefly about the company, about your journey in the company, and what you are doing today?

\section{Vision}

1. Can you describe a vision of the company?

2. How is the vision communicated in the organization?

3. Are you inspired by the vision? How does the vision help you in your daily work?

4. What else guides you in your daily work decisions?

\section{Leadership}

5. How would you describe your top manager and supervisor?

6. How well do you connect with your top manager and supervisor?

7. Do you have any role model in this organization?

8. Do you think that the top manager inspires and drives you toward a common goal?

9. Do you think that the management is very open and communicative? 
10. Do you think that the management listens to your suggestions or opinions in any form?

11. Do you often work in groups? Do you think that the whole group strives to achieve the same goal? Do the group members help each other, or do you think that each member has her or his own goals and agenda?

12. What are your thoughts regarding team work? Do you think individual work is more appreciated or group work is more appreciated?

13. How often is the top manager available? What are your thoughts and comments about handling the work in his absence?

\section{Empowerment}

14. Do you believe that you are well informed about the plans of the company or its major projects?

15. Do you have any responsibility for other employees in the company? If yes, to what extent?

16. Do you get enough information to do a good job or do you have to collect information? Where do you get this information? From the top manager, managers, or other employees? From others outside the company?

17. Do you think that the management has information and plans that the employees are not aware of?

18. Do you have a clear responsibility area? What would happen if you find a problem that is not relevant for your area? Do you get support from other employees or do you hand over the problem to a manager?

19. What do you enjoy most while working for this company?

20. Describe your motivation or inspiration for working here.

21. Can you tell us about your achievements, motivations, and challenges? Can you give some examples?

\section{Closing question}

In one sentence, describe your role as an employee of this company.

Open Access This article is distributed under the terms of the Creative Commons Attribution 4.0 International License (http://creativecommons.org/licenses/by/4.0/), which permits unrestricted use, distribution, and reproduction in any medium, provided you give appropriate credit to the original author(s) and the source, provide a link to the Creative Commons license, and indicate if changes were made.

\section{References}

Andersson S, Evangelista F (2006) The entrepreneur in the born global firm in Australia and Sweden. J Small Bus Ent Dev 13(4):642-659

Andersson S, Florén H (2011) Differences in managerial behavior between small international and noninternational firms. J Int Entrep 9(3):233-258 
Andersson S, Wictor I (2003) Innovative internationalisation in new firms: born globals - the Swedish case. J Int Entrep 1:249-276

Aspelund A, Madsen T, Moen Ø (2007) A review of the foundation, international marketing strategies, and performance of international new ventures. Eur J Marketing 41(11/12):1423-1448

Bass BM (1996) Transformational leadership redux. Leadership Quart 6:463-478

Bass BM (1999) Two decades of research and development in transformational leadership. Eur J Work and Organ Psy 8(1):9-32

Bass BM, Avolio BJ (eds) (1994) Improving organizational effectiveness through transformational leadership. Sage Publications, Thousand Oaks, CA

Block P (2016) The empowered manager: positive political skills at work, 2nd edn. Sons, John Wiley \&

Butts M, Vandenberg R, DeJoy D, Schaffer B, Wilson M (2009) Individual reactions to high involvement work processes: investigating the role of empowerment and perceived organizational support. J Occup Health Psych 14(2):122-136

Carton R, Hofer C (2006) Measuring organizational performance. Metrics for entrepreneurship and strategic management research. Edward Elgar, Cheltenham

Cavusgil ST, Knight G (2009) Born global firms: a new international enterprise. Business Expert Press, New York

Cavusgil S, Knight GJ (2015) The born global firm: an entrepreneurial and capabilities perspective on early and rapid internationalization. J Int Bus Stud 46(1):3-16

Cesinger B, Danko A, Bouncken R (2012) Born globals: (almost) 20 years of research and still not 'grown up'? Int J Entrep Small Bus 15(2):171-190

Choi J (2006) A motivational theory of charismatic leadership: envisioning, empathy, and empowerment. J Leadersh Organ Stud 13(1):24-43

Conger JA, Kanungo RN (1998) Charismatic leadership in organizations. Sage Publications, Thousand Oaks, CA

Crick D (2009) The internationalisation of born global and international new venture SMEs. Int Marketing Rev 26(4/5):453-476

Dewettinck K, Ameijde MV (2010) Linking leadership empowerment behaviour to employee attitudes and behavioural intentions. Pers Rev 40(3):284-305

Efrat K, Shoham A (2012) Born global firms: the differences between their short- and long-term performance drivers. J World Bus 47:675-685

Eisenhardt KM, Graebner ME, Sonenshein S (2016) From the editors-grand challenges and inductive methods: rigor without rigor mortis. Acad Manag J 59(4):1113-1123

Etemad HJ (2016) Special thematic issue on international interactions and activities of university-based technology entrepreneurship. J Int Entrep 14(3):277-284

Foster RD, Akdere M (2007) Effective organizational vision: implications for human resource development. J Eur Ind Train 31(2):100-111

Gabrielsson M (2005) Branding strategies of born globals. J Int Entrep 3(3):199-222

Ghannad N (2013) The role of the entrepreneur in the international new venture-opening the black box. Halmstad, Sweden: Halmstad University. Dissertation No. 3

Gioia DA, Corley KG, Hamilton JL (2013) Seeking qualitative rigor in inductive research: notes on the Gioia methodology. Organ Res Meth 16(1):15-31

Greasley K, Bryman A, Dainty A, Price A, Naismith N, Soetanto R (2008) Understanding empowerment from an employee perspective: what does it mean and do they want it? Team Perform Manag 14(1/2):39-55

Harveston PD, Kedia BL, Davis PS (2000) Internationalization of born global and gradual globalizing firms: the impact of the manager. Adv Competitiveness Res 8(1):92-99

Honold L (1997) A review of the literature on employee empowerment. Empowerment Organ 5(4):202-212

Judge TA, Piccolo RF (2004) Transformational and transactional leadership: a meta-analytic test of their relative validity. J Appl Psych 89:755-768

Kantabutra S, Avery GC (2010) The power of vision: statements that resonate. J Bus Strat 31(2):37-45

Knight, G. (2015) Born global firms: evolution of a contemporary phenomenon. In Zou S, Xu H, Shi, L (Eds.) Entrepreneurship in international marketing (Advances in International Marketing, Volume 25) Emerald Group Publishing Limited, pp.3-19.

Knight G, Cavusgil ST (2004) Innovation, organizational capabilities, and the born-global firm. J Int Bus Stud 35(2):124-141

Kunday Ö, Șengüler EP (2015) A study on factors affecting the internationalization process of small and medium enterprises (SMEs). Procedia-Soc Behav Sci 195(2):972-981

Lee M, Koh J (2001) Is empowerment really a new concept? Int J Hum Resour Manag Management 12(4): 684-695 
Lipton M (1996) Demystifying the development of an organizational vision. Sloan Manag Rev 27(4):83-91

Madsen TK, Servais P (1997) The internationalisation of born globals: an evolutionary process? Int Bus Rev 6(6):561-583

Michna A, Meczynska A, Kmieciak R, Sekowska R (2011) Relationships between empowerment, innovativeness, internationalization and performance of polish SMEs: future research directions. J Marketing Dev Competitiveness 5(5):46-63

Mintzberg H (1973) The nature of managerial work. Harper \& Row, New York

Mort GS, Weerawardena J, Liesch P (2012) Advancing entrepreneurial marketing: evidence from born global firms. Eur J Marketing 46(3/4):542-561

Nummela N, Saarenketo S, Puumalainen K (2004) A global mindset - a prerequisite for successful internationalization? Can J Adm Sci 2(1):51-64

Oviatt BM, McDougall PP (1995) Global start-ups: entrepreneurs on a worldwide stage. Acad Manage Exec $9(2): 30-44$

Oviatt BM, McDougall PP (1997) Challenges for internationalisation process theory: the case of international new ventures. Manag Int Rev 37(2):85-99

Oviatt BM, McDougall PP, Scott S (1994) Explaining the formation of international new ventures. J Bus Ventur 9(6):469-487

Oviatt BM, McDougall PP, Shrader RC (2003) A comparison of international and domestic new ventures. J Int Entrep 1(1):59-82

Özaralli N (2003) Effects of transformational leadership on empowerment and team effectiveness. Leadership Org Dev J 24(6):335-344

Pech RJ (2009) Delegating and devolving power: a case study of engaged employees. J Bus Strat 30(1):27-32

Petter J, Byrnes P, Choi DL, Fegan F, Miller R (2002) Dimensions and patterns in employee empowerment: assessing what matters to street-level bureaucrats. J Public Admin Res Theory 12(3):377-400

Pitts DW (2005) Leadership, empowerment, and public organizations. Rev Pub Personnel Admin 25(1):5-28

Quinn R, Spreitzer G (1997) The road to empowerment: seven questions every leader should consider. Organ Dyn 26(2):37-49

Randolph W (1995) Navigating the journey to empowerment. Organ Dyn 23(4):19-32

Rialp A, Rialp J, Knight G (2005) The phenomenon of early internationalizing firms: what do we know after a decade (1993-2003) of scientific inquiry? Int Bus Rev 14(2):147-166

Seibert SE, Silver RS, Randolph WA (2004) Taking empowerment to the next level: a multiple-level model of empowerment, performance, and satisfaction. Acad Manag J 47(3):332-349

Servantie V, Cabrol M, Guieu G, Boissin J-P (2016) Is international entrepreneurship a field? A bibliometric analysis of the literature (1989-2015). J Int Entrep 14(2):168-212

Smith BN, Montagno RV, Kuzmenko TN (2004) Transformational and servant leadership: content and contextual comparisons. J Leadership Organ Stud 10(4):80-91

Spence M (2003) International strategy formation in small Canadian high-technology companies-a case study approach. J Int Entrep 1:277-296

Spreitzer GM (1995) Psychological empowerment in the workplace: dimensions, measurement, and validation. Acad Manag J 38:1442-1465

Tanev S (2012) Global from the start: the characteristics of born-global firms in the technology sector. Tech Innov Manag Rev March:5-8

Wictor I (2016) Value chain activities in born global companies. In: Etemad H, Denicolai S, Hagen B, Zucchella A (eds) The changing global economy and its impact on international entrepreneurship. Edward Elgar Publishing, Cheltenham, pp 198-228

Wictor I, Andersson S (2012) The importance of vision in born global companies. In: Hörte SA (ed) Research on technology, innovation and marketing management 2009-2011: introducing the research area of innovation science. Halmstad University, Halmstad

Yang SB, Choi SO (2009) Employee empowerment and team performance: autonomy, responsibility, information, and creativity. Team Perform Manag 15(5/6):289-301

Zaccaro SJ, Banks D (2004) Leader, visioning and adaptability: bridging the gap between research and practice on developing the ability to manage change. Hum Resour Manag 43(4):367-380 